JURNAL KETAHANAN NASIONAL

Vol.23, No.3, Desember 2017, Hal 338-358

DOI:http://dx.doi.org/ 10.22146/jkn.28184

ISSN:0853-9340(Print), ISSN:2527-9688(Online)

Online sejak 28 Desember 2015 di :http://jurnal.ugm.ac.id/JKN

VOLUME 23

No. 3, Desember 2017

Halaman 338-358

\title{
Membangun Ketahanan Informasi Nasional Dalam Komunikasi Kesehatan Bagi Kalangan Perempuan Urban Di Jakarta
}

\author{
Ditha Prasanti \\ Program Studi Ilmu Komunikasi, Fakultas Ilmu Komunikasi, Universitas Padjadjaran \\ email: ditha.prasanti@gmail.com \\ Dinda Rakhma Fitriani \\ Jurusan Ilmu Komunikasi, Universitas Gunadharma \\ Email:dinda_rakhma@yahoo.com
}

\begin{abstract}
This article was the result of research conducted by the author with the title "Building National Information Security in Health Communication for Urban Women in Jakarta". This study originated from health problems that became primary needs in daily life, so there was a process of health communication to met those needs. Not only for individuals, health was also a factor supporting the successful development of national resilience of a country. Reflecting from the saying "in a healthy body, there was a strong soul", the authors saw an effort to built the resilience of national information in health communication for urban women in Jakarta. In this digital era, the process of health communication performed by urban women was very interesting to be studied.

This research used qualitative approach with case study method. Data collection techniques used were observation, in-depth interviews, and documentation studies.

The result of the research showed that there was an effort to built National Information Security in Health Communication for urban women in Jakarta: (1) Ensuring the existence of credible sources and experts in the health sector; (2) Cognitive filtering of received health messages to avoided hoaxes; (3) Selecting credible media as relevant health communication channels in the health sector; (4) Be active in cross-checking the effects or outcomes of health information messages; (5) Join community movements that cared about accurate health information.
\end{abstract}

\section{Keywords: Resilience of National Information, Health Communication, Urban Women}

\begin{abstract}
ABSTRAK
Artikel ini merupakan hasil penelitian yang dilakukan peneliti dengan judul "Membangun Ketahanan Informasi Nasional dalam Komunikasi Kesehatan bagi Kalangan Perempuan Urban di Jakarta". Penelitian ini berawal dari masalah kesehatan yang menjadi kebutuhan primer dalam kehidupan sehari-hari, sehingga terjadilah proses komunikasi kesehatan untuk memenuhi kebutuhan tersebut. Tidak hanya bagi individu, kesehatan pun menjadi faktor penunjang keberhasilan pembangunan ketahanan nasional suatu negara. Bercermin dari pepatah "dalam tubuh yang sehat, terdapat jiwa yang kuat", peneliti melihat adanya upaya membangun ketahanan informasi nasional dalam komunikasi kesehatan bagi kalangan perempuan urban di Jakarta. Di era digital ini, proses komunikasi kesehatan yang dilakukan oleh perempuan urban sangat menarik untuk dikaji.

Penelitian ini menggunakan pendekatan kualitatif dengan metode studi kasus. Teknik pengumpulan data yang digunakan adalah observasi, wawancara mendalam, dan studi dokumentasi.

Hasil penelitian menunjukkan bahwa adanya upaya membangun ketahanan informasi nasional dalam komunikasi kesehatan bagi kalangan perempuan urban di Jakarta ini yaitu: (1) Memastikan adanya sumber yang kredibel dan ahli di bidang kesehatan; (2) Melakukan filterisasi kognitif pada pesan kesehatan yang diterima agar terhindar dari hoax; (3) Memilih media yang kredibel sebagai saluran komunikasi kesehatan yang relevan di bidang
\end{abstract}


kesehatan; (4) Bersikap aktif dalam melakukan cross check efek atau hasil dari pesan informasi kesehatan; (5) Bergabung dengan gerakan komunitas yang peduli kepada informasi kesehatan yang akurat.

\section{Kata Kunci : Ketahanan Informasi Nasional, Komunikasi Kesehatan, Perempuan Urban}

\section{PENGANTAR}

Tak dapat dipungkiri lagi bahwa kesehatan merupakan kebutuhan utama manusia yang harus mendapatkan perhatian khusus. Jika sistem kesehatan yang berlaku di suatu negara terganggu, maka hal ini akan berdampak pula pada sistem ketahanan nasional negara tersebut. Oleh karena itu, pemerintah pun menetapkan prioritas program kesehatan yang harus dicapai tertuang dalam Suistanable Development Goals (SDGs) pada periode 2015-2030. Sustainable Development Goals (SDGs) atau Tujuan Pembangunan Berkelanjutan merupakan agenda global menggantikan Millennium Development Goals (MDGs), yang sudah mengubah wajah dunia dalam 15 tahun terakhir.

Kesehatan di Indonesia tentu membutuhkan upaya dalam melakukan rekonstruksi pembangunan sistem kesehatan nasional dengan tetap berpegang teguh dalam merawat nilai-nilai kebangsaan dan keindonesiaan. Untuk mewujudkan serta menunjang akselerasi pencapaian peran strategis tersebut, diperlukan Sistem Kesehatan Nasional (SKN) yang merupakan pilar dari sistem ketahanan nasional sebagaimana diatur dalam Peraturan Presiden Nomor 72 Tahun 2012 yang menjadi peta jalan dalam mewujudkan masyarakat sehat dengan derajat kesehatan setinggi-tingginya. WHO (2000) mendefinisikan bahwa sistem kesehatan merupakan aktivitas yang memiliki tujuan utama untuk meningkatkan, memperbaiki, atau merawat kesehatan. Dalam perkembangan para ahli mengganti istilah health system dengan health care system karena lingkupnya yang sangat bergantung kebijakan suatu negara (WHO: 2007).

Dalam penelitian ini, peneliti tertarik untuk mengangkat tentang kajian komunikasi kesehatan yang berdampak pada ketahanan informasi nasional. Penelitian ini berawal dari masalah kesehatan yang serius, sehingga terjadilah proses komunikasi kesehatan untuk memenuhi kebutuhan tersebut. Tidak hanya bagi individu, kesehatan pun menjadi faktor penunjang keberhasilan pembangunan ketahanan nasional suatu negara. Bercermin dari pepatah "dalam tubuh yang sehat, terdapat jiwa yang kuat", peneliti melihat adanya upaya membangun ketahanan informasi nasional dalam komunikasi kesehatan bagi kalangan perempuan urban di Jakarta. Di era digital ini, upaya membangun ketahanan informasi nasional dalam proses komunikasi kesehatan yang dilakukan oleh perempuan urban sangat menarik untuk dikaji. Hal ini karena perkembangan era informasi digital yang menjadikan perempuan urban turut mengoptimalkan peran media digital dalam memenuhi kebutuhan informasi kesehatannya.

Berbicara mengenai ketahanan informasi nasional tentu tidak akan lepas dari ketahanan nasional itu sendiri. Ketahanan nasional sebagai istilah yang mulai dikenal dan dipergunakan pada permulaam tahun 1960an. Istilah ketahanan nasional untuk pertama kali dikemukan oleh Presiden Republik Indonesia Soekarno. Kemudian pada tahun 1962 mulai diupayakan secara khusus untuk mengembangkan gagasan ketahanan nasional di Sekolah Staf dan Komando Angkatan Darat Bandung (Amal dan Armawi, 2005:2). 
Ketahanan nasional adalah suatu kondisi dinamis suatu bangsa, yang berisi keuletan dan ketangguhan, yang mengandung kemampuan mengembangkan kekuatan nasional dalam menghadapi dan mengatasi segala ancaman, gangguan, hambatan dan tantangan, baik yang datang dari luar maupun dari dalam negeri, yang langsung maupun tidak langsung membahayakan integritas, identitas, kelangsungan hidup bangsa dan negara serta perjuangan dalam mengejar tujuan nasional Indonesia (Suradinata, 2005:47). Perlu diketahui juga bahwa ketahanan nasional ini berdampak dalam setiap aspek ruang kehidupan manusia. Berikut ini peneliti menggambarkan beberapa hasil penelitian terdahulu yang berhubungan dengan ketahanan nasional.

Penelitian yang telah dilakukan Saridewi, dkk (2015) menggambarkan tentang penggunaan TIK sebagai usaha untuk memperoleh informasi agar tetap dapat memberikan ASI selama ibu bekerja. Ibu menyusui mendapatkan informasi mengenai laktasi melalui buku-buku tentang ASI/ menyusui, konsultasi atau mengikuti pelatihan laktasi dengan narasumber laktasi secara langsung. Pihak medis berwenang yang mendukung dalam pemberian ASI atau konselor laktasi/ menyusui dalam penelitian ini selanjutnya disebut sebagai narasumber laktasi. Beberapa kendala yang dihadapi melalui cara tersebut, yaitu: keterbatasan waktu, biaya, keterbatasan narasumber laktasi di daerah terpencil. Kendala yang dihadapi sebagai ibu bekerja dengan banyak kesibukan tetapi memiliki niat dan usaha untuk tetap memberikan ASI mendorong rasa optimis para informan untuk mencari informasi. Para informan mendapatkan solusi dengan memanfaatkan kemudahan penggunaan
TIK. Para informan menggunakan browser yang terpasang dalam perangkat TIK seperti Internet Explorer, Chrome, Mozilla dan lain sebagainya. Melalui browser para informan dapat mengakses situs-situs yang menyediakan layanan mesin pencarian informasi seperti Google, Bing, Yahoo, dan sebagainya. Mesin pencari tersebut kemudian menampilkan tautan seluruh situs yang mengandung kata kunci yang telah dimasukkan.

Penelitian lain yang telah dilakukan Tundung (2017) menggambarkan tentang pemeriksaan tingkat kelengkapan dan kematangan pengelolaan keamanan sistem informasi elektronik menjadi penting karena merupakan bentuk pengawasan dan pengendalian infrastruktur teknologi informasi yang disarankan oleh Kementerian Komunikasi dan Informasi bagi penyelenggara pelayanan publik yang berbasis sistem informasi elektronik. Ketahanan sistem informasi pendukung layanan administrasi kependudukan menjadi aspek yang sangat penting diukur mengingat kinerja tata kelola TIK akan terganggu jika informasi sebagai salah satu objek utama tata kelola TIK mengalami masalah keamanan informasi yang menyangkut kerahasiaan, keutuhan dan ketersediaan data. Mengingat luasnya khasanah pelayanan administrasi kependudukan maka penelitian dibatasi dalam lingkungan Dinas Kependudukan dan Pencatatan Sipil (Dindukcapil) Kota Yogyakarta. Berdasarkan uraian latar belakang di atas permasalahan yang diajukan dalam penelitian ini yaitu bagaimana tingkat kelengkapan dan kematangan pengelolaan keamanan Sistem Informasi Administrasi Kependudukan (SIAK) Dindukcapil Kota Yogyakarta.

Selanjutnya, penelitian yang dilakukan Azam (2010) tentang ketahanan nasional juga 
menjelaskan krisis moneter yang menerpa Indonesia tahun 1997 berkembang menjadi krisis multidimensi, menyebabkan meletusnya era reformasi dengan runtuhnya rezim Orde Baru tahun 1998, ditandai mundurnya Presiden Soeharto diganti Wapres B. J. Habibie menjadi Presiden RI ketiga. Krisis itu terutama tahun 1997-1999, pusaran awal era reformasi. Ketahanan Nasional saat itu pada titik nadir, nasib Negara Kesatuan Republik Indonesia (NKRI) dalam taruhan tetap berdiri atau ambruk sebagai nation state. Saat itu berbagai demonstrasi meletus, mencaci-maki rezim berkuasa, menghujat Orde Baru yang gagal memakmurkan rakyat, menuntut segera diatasinya krisis dan ditegakkannya hukum yang keras atas para koruptor. Pemerintah pun limbung, tidak mampu memenuhi rakyat, tidak berdaya merespons perubahan zaman, dan gagal mengatasi krisis. Akibatnya masyarakat kian kecewa dan frustrasi, maka meletuslah kemarahan yang menimbulkan chaos dan anarchy. Semua kejadian itu diliput lengkap oleh pers, tanpa tedheng alingaling, berani dan gamblang, yang sangat dirasakan manfaatnya oleh masyarakat, terutama demi memenuhi hak rakyat untuk tahu (the people's right to know). Peranan pers sangat penting dan strategis dalam memperkuat ketahanan nasional. Ada korelasi yang sinergi dan konvergensi antara pers dan ketahanan nasional dalam memperkokoh dan memakmurkan kepentingan nasional, dan akan membimbing negara bangsa dalam mencapai ketahanan nasional yang tangguh.

Mugasejati dan Armawi (2000) dalam penelitian yang sejenis tentang "Ketahanan Nasional Dan Globalisasi, Sebuah Agenda Riset" menunjukkan bahwa dalam beberapa tahun ini sering terdengar istilah globalisasi. Pada umumnya globalisasi digunakan untuk menunjukkan adanya perubahan-perubahan ekonomi dunia yang berlangsung amat drastis, terutama perubahan dalam teknologi transportasi dalam komunikasi, aliran finansial dan perdagangan yang semakin terinternasionalisasi serta transisi arena persaingan ekonomi dari pasar nasional ke pasar global. Konsep globalisasi dikaitkan dengan dua pengertian sekaligus, yaitu sebagai ancaman terhadap eksistensi masyarakat atau suatu negara bangsa dan sebagai peluang, karena globalisasi dianggap memberikan kesempatan bagi banyak negara untuk mencapai masyarakat dunia yang sederajad melalui peningkatan daya saing, efsiensi, standardisasi, demokratisasi, penghormatan terhadap HAM dan lain-lain.

Dalam sisi lain, penelitian yang dilakukan oleh Nursaid dan Armawi (2016) berbicara tentang mengukur ketahanan ekonomi keluarga. Hasil penelitian menunjukkan bahwa keluarga kelompok Sekar Arum tidak terklasifikasi dalam keluarga miskin. Keluarga anggota kelompok Sekar Arum memiliki ketahanan ekonomi keluarga yang tangguh. Kendala yang dihadapi berupa sistem marketing produk batik tulis yang belum optimal, sistem laporan keuangan yang kurang profesional, aksesibilitas yang kurang mendukung, ketersediaan jaringan komunikasi yang sangat minim, dan kurangnya kesadaran dan ketertarikan generasi muda untuk membatik. Rekomendasi berupa pengoptimalan marketing berbagai produk batik tulis Giriloyo, pendampingan pembuatan sistem laporan keuangan, menjalin komunikasi dengan berbagai pihak untuk perbaikan aksesibilitas, menjalin komunikasi intens dengan provider dan pemerintah kabupaten, dan bekerjasama dengan pemerintah untuk pendidikan dan proses regenerasi. 
Penelitian lainnya yang dilakukan oleh Rinta (2015) tentang ketahanan nasional dalam kondisi psikologi remaja. Data penelitiannya didapatkan dari wawancara mendalam pada tujuh orang informan yang terdiri atas lima orang guru yang menangani Bimbingan Konseling (BK) dan sisanya merupakan siswa yang aktif sebagai konselor sebaya di Pusat Informasi dan Konseling Remaja. Analisis data melalui tahap pengkodean, yaitu open coding, dan axial coding. Hasil penelitian ini menunjukkan ada dua peran pendidikan seksual bagi ketahanan psikologi remaja, yaitu (1) menjawab rasa ingin tahu remaja melalui pemberian informasi yang benar berkaitan dengan seksualitas dan (2) membentuk sikap positif remaja dalam menghadapi perilaku seksual dini dan pranikah. Dampak pendidikan seksual bagi ketahanan psikologi remaja ialah terciptanya remaja yang memiliki perilaku seksual yang positif dan menciptakan ketahanan psikologis remaja dalam hal perilaku seksual.

Berbagai literatur penelitian terdahulu di atas memperkaya keilmuan peneliti mengenai betapa luasnya jangkauan ketahanan nasional sehingga dapat dikaji dari beragamnya ruang aspek yang berhubungan dengan kehidupan manusia. Begitupun halnya dengan penelitian yang peneliti telah lakukan ini, peneliti melihat ruang aspek yang lain tentang ketahanan nasional, yaitu adanya ketahanan informasi nasional dalam proses komunikasi kesehatan yang terjadi bagi keluarga urban di era digital. Masalah ini sangat penting untuk diteliti mengingat perkembangan teknologi yang semakin canggih di Indonesia, dan berdampak dalam berbagai konteks komunikasi, khususnya dalam penelitian ini adalah komunikasi kesehatan.

Sebagai salah satu rangkaian dalam proses komunikasi kesehatan, maka untuk memenuhi kebutuhan informasi kesehatannya, peneliti melihat adanya kecenderungan informan dalam mengoptimalkan peran media digital. Hal inilah yang kemudian akan berdampak pada ketahanan informasi nasional. Oleh karena itu, dalam penelitian ini, peneliti menggunakan pendekatan penelitian kualitatif dengan metode studi kasus.

Pendekatan studi kasus ini merupakan pendekatan yang paling pas untuk mengungkap penelitian ini. Creswell (2010: 61) mendefinisikan studi kasus dengan,

"A case study is an exploration of a "bounded system" or a case (or multiple cases) over time through detailed, in-depth data collection involving multiple sources of information rich in context.This bounded system is bounded by time and place, and it is the case being studied - a program, an event, an activity, or individuals. Multiple sources of information include observations, interviews, audio-visual material, and documents and reports".

Tujuan studi kasus adalah untuk memberikan gambaran secara mendetail tentang latar belakang, sifat-sifat serta karakterkarakter yang khas dari kasus, ataupun status dari individu yang bersangkutan, dan sifatsifat khas di atas akan dijadikan suatu hal yang bersifat umum (Nazir, 2003: 66). Studi kasus bersifat holistik dan menganggap kasus sebagai entitas menyeluruh dan bukan sebagai kumpulan bagian-bagian atau kumpulan skor mengenai variabel (Ragin dalam Mulyana, 2002: 203).

Proses pengumpulan dan analisis data dengan demikian tidak memiliki batasan kronologis. Komponen-komponen analisis data seperti reduksi data, penyajian data, dan penarikan kesimpulan juga saling berhubungan satu sama lain, baik selama masa pengumpulan 
data maupun setelah masa pengumpulan data. Interaksi antara komponen-komponen analisis data dengan pengumpulan data ditunjukkan pada gambar 1 .

Gambar 1

Komponen Analisis data Model Interaktif (Interactive Model)

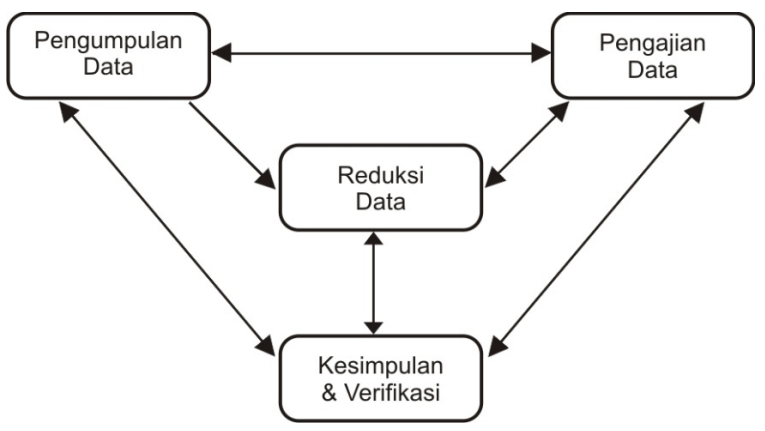

Sumber : Salim, 2006

Salim (2006:22-23) menjelaskan tiga komponen analisis data tersebut sebagai berikut: (1). Pengumpulan data (data collection), dapat diperoleh melalui proses observasi, wawancara mendalam, dan studi dokumentasi. (2). Reduksi data (data reduction) yaitu proses pemilihan, pemusatan perhatian pada penyederhanaan, abstraksi, dan transformasi data kasar yang di peroleh di lapangan. (3). Penyajian data (data display) yaitu deskripsi kumpulan informasi tersusun yang memungkinkan untuk melakukan penarikan kesimpulan dan pengambilan tindakan. Bentuk yang lazim digunakan digunakan adalah teks naratif. (4). Penarikan kesimpulan dan verifikasi (conclusion drawing and verification) dilakukan sejak pengumpulan data dimulai. Peneliti mencari makna dari setiap gejala yang diperoleh di lapangan, mencatat keteraturan atau pola penjelasan dan konfigurasi yang mungkin ada, alur kausalitas, dan proposisi. Selama penelitian masih berlangsung, setiap kesimpulan yang ditetapkan akan terus-menerus diverifikasi, sehingga benar-benar diperoleh kesimpulan yang valid dan kokoh.

Dalam penelitian ini, peneliti mengambil informan penelitian dari kalangan perempuan urban di Jakarta, sebagai representasi dari salah satu kota besar yang ada di Indonesia. Teknik pengambilan informan yang digunakan adalah teknik sampling purposive, yaitu mengambil informan sesuai dengan kebutuhan penelitian, yaitu 4 informan: (1). Adn, perempuan karir, Jakarta, (2). Lda, perempuan karir, Jakarta, (3). Dwf, perempuan karir, Jakarta, (4). Kna, ibu rumah tangga, Jakarta.

Berdasarkan latar belakang masalah di atas, peneliti semakin tertarik mengeksplorasi penelitian ini dengan judul "Membangun Ketahanan Informasi Nasional Dalam Komunikasi Kesehatan Bagi Kalangan Perempuan Urban Di Jakarta". Dalam penelitian ini, peneliti juga menggunakan teori atau model komunikasi yang relevan untuk menganalisis hasil penelitian yang telah diperoleh.

\section{PEMBAHASAN}

\section{Ketahanan Informasi Nasional}

Salah satu cakupan penting dalam ketahanan nasional yang hampir terlupakan adalah ketahanan informasi nasional. Betapa pentingnya peran masyarakat, pemerintah, dan media dalam berkoordinasi menjaga ketahanan informasi nasional. Berdasarkan pengamatan literatur yang telah dilakukan, peneliti belum menemukan sebuah penelitian khusus yang mengkaji tentang ketahanan informasi nasional ini. Padahal ketahanan informasi nasional ini akan berdampak dalam berbagai konteks komunikasi yang dilakukan manusia, salah satunya adalah komunikasi kesehatan. Penulis melihat beberapa artikel online yang menyajikan tentang ketahanan informasi nasional. 
Dalam artikel yang dilansir dari www. kompasiana.com, peneliti menemukan adanya pernyataan dari Kepala Dinas Penerangan TNI Angkatan Darat (Kadispenad) Brigadir Jenderal TNI Sabrar Fadhilah, yang berkomentar bahwa Indonesia membutuhkan ketahanan informasi untuk menyikapi maraknya fitnah, hinaan, dan olokan yang menyebar dalam pengiriman berita bohong atau hoax. Dengan adanya kondisi tersebut, TNI AD mengambil langkah terobosan dengan membuat ketahanan informasi. Ketahanan informasi adalah suatu kebijakan menyaring dan mencegah berbagai informasi tidak benar dan tanpa data, termasuk penyebaran berita bohong/ hoax.

Kondisi bangsa seperti ini dihadapkan dengan kemajuan informasi dan teknologi memungkinkan bangsa besar untuk menyikapi ini, sebab selama ini kiranya hanya dikenal ketahanan ideologi, sosial, budaya dan pangan, makasekarang perlu ditambah dengan adanya ketahanan informasi. Hal ini patut diapresiasi karena Kadispenad Brigjen TNI Sabrar Fadhilah telah memberikan solusi mengenai ketahanan informasi seiring makin banyaknya berita-berita bohong/ hoax di media sosial yang sudah tak terbendung lagi. Konsep ketahanan informasi sangat dibutuhkan, agar masyarakat semakin cerdas dan berpartisipasi dalam memerangi penyebaran informasi hoax tersebut. Setidaknya dengan menyebarkan berita-berita positif, secara langsung masyarakat telah ikut memerangi berita bohong/ hoax (http://www.kompasiana.com).

Selain artikel di atas, peneliti menemukan artikel lainnya yang menguatkan peneliti untuk melakukan penelitian ini, artikel tersebut menyatakan bahwa ketahanan informasi ini sudah lebih awal ditetapkan melalui kerjasama antara Kementerian Pertahanan (Kemhan) dan Kementerian Kesehatan (Kemkes).
Kerjasama ini disahkan dengan melakukan penandatangan kesepakatan bersama tentang kerjasama dalam bidang kesehatan. Kesepakatan bersama tersebut ditandatangani oleh Menteri Pertahanan, Ryamizard Ryacudu bersama Menteri Kesehatan, Prof. Dr. dr. Nila F. Moeloek, Sp. M(K) di kantor Kementerian Pertahanan, Jakarta (www.kemhan.go.id).

Dalam artikel yang dilansir dari www. kemhan.go.id, peneliti memperoleh fakta bahwa kerjasama dalam bidang kesehatan dan pertahanan ini telah dilakukan pada 22 Juni 2015. Kerjasama tersebut bertujuan untuk meningkatkan kesehatan masyarakat sebagai potensi dan kekuatan pertahanan negara, tetapi hingga saat ini, upaya membangun ketahanan informasi nasional ini harus semakin ditingkatkan. Ruang lingkup kesepakatan bersama meliputi; sertifikasi kesehatan sarana prasarana Kemhan dan TNI, mengembangkan sistem informasi kesehatan yang terintegrasi, penyelenggaraan penelitian dan pengembangan IPTEK di bidang kesehatan untuk meningkatkan derajat kesehatan masyarakat, memperkuat kapasitas deteksi dan respon terhadap bahaya di bidang Kimia, Biologi, Radiasi, Nuklir, Eksplosif (KBRNE) aspek kesehatan untuk pertahanan negara (www.kemhan.go.id). Selanjutnya meliputi juga pendidikan, pelatihan, sertifikasi, pengembangan dan pendayagunaan tenaga kesehatan yang berwawasan kebangsaan, akreditasi kelas rumah sakit, penyelenggaraan penanggulangan penyakit dan penyehatan lingkungan dengan melibatkan institusi territorial, pengembangan kesehatan matra, penyelenggaraan bantuan kesehatan pada daerah bermasalah kesehatan, daerah terpencil, perbatasan dan kepulauan (DTPK), krisis kesehatan dan bencana, perumusan kebijakan, monitoring dan evaluasi pelaksanaan regulasi 
bidang kesehatan nasional yang tekait bidang pertahanan negara. Kerjasama antara Kemhan dan Kemkes merupakan langkah menuju terciptanya sinergitas kedua kementerian dalam rangka penguatan sistem pertahanan negara di bidang kesehatan (www.kemhan. go.id).

\section{Konsep Komunikasi Kesehatan}

Menurut Liliweri (2007), pengertian komunikasi kesehatan adalah (1). Studi yang mempelajari bagaimana cara menggunakan strategi komunikasi yang dapat mempengaruhi individu dan komunitas agar mereka dapat membuat keputusan yang tepat berkaitan dengan pengelolaan kesehatan. (2). Proses kemitraan antara para partisipan berdasarkan dialog dua arah yang di dalamnya ada suasana interaktif, ada pertukaran gagasan, ada kesepakatan mengenai kesatuan gagasan mengenai kesehatan, juga merupakan teknik dari pengirim dan penerima untuk memperoleh informasi mengenai kesehatan yang seimbang demi memperbarui pemahaman bersama, (3). Proses untuk mengembangkan atau membagi pesan kesehatan kepada audiens tertentu dengan maksud mempengaruhi pengetahuan, sikap, keyakinan mereka tentang pilihan dan perilaku hidup sehat.

Komunikasi kesehatan didefinisikan dengan beragam sesuai dengan tujuan yang ingin dicapai dalam proses komunikasinya. Tujuan komunikasi kesehatan untuk memberi informasi dan mempengaruhi keputusan individu atau komunitas, terlihat dalam definisi yang diberikan oleh New South Wales Department of Health, Australia : "Health communication is a key strategy to inform the public about health concerns and to maintain important health issues on the public agenda" (Schiavo, 2007 : 8). Sedangkan definisi komunikasi kesehatan yang lain bertujuan untuk merubah perilaku dapat dilihat dari definisi yang disampaikan oleh Clift dan Freimuth bahwa "health communication, like health education, is an approach which attempts to change a set of behaviors in a large scale target audience regarding a specific problem in a predefined period of time" (Schiavo 2007: 9).

Menurut Schiavo (2007:73) setidaknya ada 2 model untuk mendefinisikan kesehatan.

Pertama, model biomedis. Menurut model biomedis, kesehatan secara tegas dikatakan sebagai terbebas dari penyakit yang secara spesifik dinyatakan dengan tidak adanya gejala fisik yang berhubungan dengan keadaan sakit. Model ini sudah dikenal lama dengan asumsi bahwa kesehatan hanya memandang keadaan sehat atau sakit secara fisik saja. Faktor-faktor lain sebagai penyebab sakit, seperti faktor psikologis, kepercayaan, sikap, norma sosial, tradisi dan gaya hidup diabaikan oleh model ini. Sebagai akibatnya, upaya-upaya komunikasi kesehatan yang dilakukan cenderung informatif, sangat ilmiah, indoktrinasi, efisien dan terfokus pada pendekatan komunikasi top-down yang membatasi penyampaian isu-isu kesehatan dan penanggulangan masalahnya. Model ini kurang berempati terhadap perasaan dan pengalaman sosial pasien.

Kedua, model biopsikososial. World Health Organization pada 1946 menyatakan bahwa kesehatan adalah " $a$ state of complete psysical, mental and social well being, and not merely the absence of desease or infirmity". Definisi kesehatan dari WHO tidak memasukkan dimensi budaya yang boleh jadi dianggap menjadi bagian yang tidak terpisahkan dari dimensi sosial yang dimunculkan dalam definisi tersebut. Kata 
kunci dari definisi ini adalah keseimbangan hubungan antara kondisi fisik, psikis dan sosial. Menurut model biopsikososial, kesehatan yang buruk bukan hanya fenomena fisik tetapi juga kondisi perasaan atau psikologis, anggapan tentang sakit dan peristiwa yang terjadi pada seseorang. Model ini menekankan pada pendekatan yang berfokus pada pasien. Model yang cenderung menekankan pada komunikasi empatik ini sekarang banyak diterapkan sebagai pengganti model biomedis (Fredman dan Di Matteo dalam Schiavo 2007 : 58).

Komunikasi kesehatan menyangkut bagaimana manusia bereaksi ketika berhadapan dengan masalah yang berhubungan dengan kesehatan. Dalam komunikasi kesehatan, fokusnya adalah pertukaran informasi secara spesifik dan faktor-faktor yang mempengaruhi proses pertukaran informasi ini (Pettegrew:1982). Pertukaran informasi dapat terjadi secara verbal atau nonverbal, oral atau tertulis, personal atau impersonal. Secara umum komunikasi kesehatan merupakan aplikasi dari konsep dan teori komunikasi dalam proses pertukaran informasi yang muncul mengenai masalah yang menyangkut tentang kesehatan.

Dalam menjelaskan komunikasi kesehatan sehubungan dengan penelitian ini, model pendekatan biopsikososial yang paling tepat adalah model interaksi simbolik, dimana individu dilihat sebagai orang-orang yang melakukan interaksi satu sama lain bukan individu yang menjadi bagian dari sistem sosial yang luas.

Dalam berkomunikasi atau dalam berinteraksi masing-masing individu tidak selalu melakukan peranan sebagaimana yang ditetapkan dalam suatu sistem sosial. Masingmasing selalu mengadakan perubahan dan menyesuaikan diri dengan setiap kendala yang terdapat dalam setiap interaksi (Muzaham, 1995: 14).

Ruang lingkup komunikasi kesehatan sendiri juga meliputi berbagai hal, yaitu penyebarluasan informasi kesehatan melalui media; komunikasi dengan pasien yang meliputi informasi untuk seorang individu, misalnya informasi yang berkaitan dengan kesehatan individu, bagaimana memaksimalkan perawatan, pemberian terapi, atau penyampaian pendekatan alternatif, dan bagaimana melayani pasien secara komunikatif; informasi kesehatan untuk para konsumen demi membantu individu untuk memahami kesehatan individu, bagaimana membuat keputusan yang berkaitan dengan kesehatan individu dan keluarga; serta strategi komunikasi yang meliputi desain pilihan komunikator kesehatan, pesan-pesan kesehatan, media kesehatan, komunikan kesehatan; mereduksi hambatan komunikasi; dan menentukan konteks komunikasi kesehatan (Liliweri, 2007).

\section{Fenomena Perempuan Urban}

Kalangan masyarakat urban pada era digital ini sangat menarik untuk diteliti. Begitupun halnya kalangan perempuan urban saat ini menjadi sebuah fenomena tersendiri dalam berbagai aspek kehidupan. Berbagai penelitian pun telah dilakukan yang berkaitan dengan masyarakat urban ini. Berikut ini peneliti menggambarkan penelitian terdahulu tentang masyarakat urban.

Nediari (2013) telah melakukan penelitian tentang fenomena mal terhadap masyarakat urban di Jakarta, dan dampaknya terhadap lingkungan adalah bahwa mal memberikan pengalaman estetika bagi masyarakat urban. Estetika sebagai persepsi 
penginderaan menjadikan kunjungan ke mal sebagai pengalaman yang berharga. Walaupun mal telah menjadi destinasi dari gaya hidup masyarakat urban, budaya konsumtif bukanlah aturan baku yang selalu diikuti. Tingkat pendidikan dan keterbatasan ekonomi juga turut berperan dalam gaya hidup masyarakat urban. Kebutuhan masyarakat urban akan mal tentu dipengaruhi oleh tren yang selalu bergeser. Bangunan yang terbuka dan ramah lingkungan saat ini menjadi tren di dunia, memberikan dampak yang positif bagai perkembangan dunia interior-arsitektur. Hal ini memberikan kesadaran bagi masyarakat urban tentang pentingnya sebuah ruangan hijau terbuka dan daerah resapan air. Dampak dari bangunan mal terhadap lingkungan saat ini dapat diatasi dengan memberikan kebijakan mengenai aturan pembangunan mal di Kota Jakarta melalui Peraturan Menteri Negara Lingkungan Hidup No. 8 tahun 2010 guna mendapatkan sertifikasi bangunan hijau dari Green Building Council Indonesia.

Penelitian lain yang dilakukan Mufidah (2012) menyatakan bahwa dalam kehidupan modern ini, masyarakat perkotaan khususnya di Surabaya menuntut untuk bergaya hidup konsumsi yang serba cepat dan instan. Hal itu dikarenakan padatnya aktivitas dan kegiatan di luar rumah yang dilakukan oleh keluarga khususnya pasangan suami dan istri yang mengakibatkan berkurangnya waktu untuk berkumpul bersama keluarga apalagi makan bersama anak-anaknya. Apabila dibandingkan dengan beberapa tahun yang lalu, yakni sekitar tahun 2000-an, makan sehari-hari cenderung dilakukan di rumah di mana makanan yang disajikan merupakan hasil dari olahan sendiri. Para istri menyempatkan diri untuk memasak dan meluangkan waktunya untuk sekedar makan bersama dengan keluarganya walaupun istri tersebut juga disibukkan dengan aktifitas di luar rumah, yakni bekerja. Hal itu dilakukan agar dapat semakin mempererat rasa kasih sayang diantara mereka.

Menurut Lan (2015), perubahan yang dibawa oleh modernisasi melalui proses industrialisasi dan kemajuan teknologi informasi berdampak pada perubahan peran perempuan dalam keluarga dan di ruang publik. Jumlah perempuan yang bekerja di luar rumah semakin meningkat. Walaupun meningkatnya jumlah perempuan yang bekerja memang diharapkan dalam program pembangunan yang disponsori negara, pada dasarnya prinsip kesetaraan gender yang diperkenalkan oleh proses modernisasi tidak berjalan sebagaimana semestinya, karena negara tetap mempertahankan konsep perempuan sebagai ibu rumah tangga. Dengan kata lain, negara menerapkan kebijakan peran ganda kepada perempuan. Dalam hal ini perlu ada perubahan sikap negara, khususnya melalui perubahan sistem hukum yang mencerminkan pola relasi yang setara dan adil di antara laki-laki dan perempuan, terutama ketika perempuan sebagai ibu rumah tangga juga memberi kontribusi ekonomi dengan bekerja di luar rumah.

Penelitian lainnya, dilakukan oleh Gaffar (2012) tentang Sihir Iklan bagi Masyarakat Urban. Apa yang dikonsumsi menentukan identitas, kelas dan untuk menunjukkan siapa mereka sebenarnya. Pergeseran gaya hidup pada masyarakat perkotaan mengalami perkembangan pesat dalam berbagai bentuk, gaya hidup melalui apa yang dikonsumsi terus berkembang, bergesernya gaya hidup dan tipologi ekspresi perwujudan diri masyarakat pada apa yang dikonsumsi yang didapatkan melalui iklan yang sesungguhnya berorientasi pada keuntungan dari suatu produk telah 
masuk ke dalam diri masyarakat. Iklan mempengaruhi masyarakat dari produk yang mereka jual kemudian ke orientasi citra produk, maka telah terjadi perkembangan yang pesat berkaitan dengan makna sistem tanda iklan secara semiosis beserta implikasinya terhadap masyarakat. Puncak dari iklan dalam mempengaruhi gaya hidup pada apa yang dikonsusmi masyarakat terletak pada citra produk yang dibentuk sedemikian rupa, dengan demikian nilai-nilai kebudayaan yang ada pada masyarakat sekarang terekspresi melalui iklan di media massa, yang lebih mementingkan nilai citra, jika dibandingkan dengan nilai guna produk yang dikonsumsi. Apa yang dikonsumsi tidak lagi berkaitan dengan kebutuhan atau nilai guna, melainkan ada unsur gaya hidup yang ada pada barang digunakan oleh masyarakat.

Fenomena perkotaan yang ditandai dengan semakin banyak perempuan yang bekerja ini sepertinya mendorong Universal Networks International untuk melakukan studi. Hasil studi psikografi Universal Networks International yang bekerja sama dengan Synovate menghasilkan potret perempuan urban modern yang unik yang disebut High Heeled Warriors (Fazriyati: 2011). Perempuan urban modern Indonesia dikatakan memiliki 10 sifat unik sebagai berikut: (1) Percaya bahwa memiliki karier adalah cara untuk berkontribusi kepada keluarga, dan prioritasnya dalam memberi produk juga untuk memberikan yang terbaik bagi keluarganya; (2) Sahabat adalah bagian terpenting dalam hidupnya; (3) Terpelajar dan selalu mencari informasi terbaru agar bisa merencanakan kehidupan dengan lebih baik; (4) Berorientasi sukses dalam setiap aspek kehidupan, termasuk sukses dalam membina keluarga harmonis dan membesarkan anak-anak; (5) Berorientasi karier dan kepuasan pribadi, memiliki rasa penghormatan atas diri sendiri serta kebanggaan dengan menjadi perempuan dan ibu bekerja yang sukses dan modern; (6) Ingin terlihat cerdas dan modern (intelek dan melek fashion) dalam berpenampilan dan membawakan diri; (7) Melek keuangan (tidak melihat dirinya sebagai sosok pasif dalam pengambilan keputusan, terutama di keluarga), secara berkala mendiskusikan keluarga dengan suami, dan merencanakan keuangan dengan lebih baik untuk hidup lebih mapan; (8) Melek teknologi. Agar selalu terhubung dengan keluarga dan teman, mereka termotivasi untuk memiliki teknologi terkini, (9) Peduli pada kesehatan. Fitness dan aerobik menjadi pilihan untuk membantunya mencegah penyakit dan meningkatkan nutrisi sebagai bagian dari peningkatan kualitas hidupnya, dan (10) Ingin aman dan nyaman dengan menghargai relaksasi dan memanjakan diri. Namun, kenyamanan ini tidak hanya untuk dirinya pribadi melainkan dengan merencanakan masa depan keluarga atau kehidupan aman dan nyaman untuk keluarganya.

\section{Membangun Ketahanan Informasi Nasional Dalam Komunikasi Kesehatan}

Berdasarkan penelitian yang telah dilakukan, peneliti mengeksplorasi hasil temuan yang baru tentang adanya upaya membangun ketahanan informasi nasional dalam komunikasi kesehatan bagi kalangan perempuan urban di Jakarta. Hasil penelitian peneliti juga diperkuat dengan penelurusan dokumentasi artikel yang dilansir dari http:// www.timesindonesia.co,id, yang menyatakan bahwa informasi atau berita hoax jelas memperlemah ketahanan informasi nasional, 
sehingga masyarakat pun menjadi sangat rentan mengalami gesekan akibat informasi hoax yang ada.

Peneliti lapangan LSI Area Jawa Timur, Juni Tristanto L Putra, dalam artikel ini, juga mengatakan kepada TIMES Indonesia, Jumat $(10 / 2 / 2017)$ bahwa,

"Di era digital, setiap orang bisa dengan bebas menulis artikel, opini, berita dan lainlain. Kemudian mempublishnya. Sebenarnya ini menjadi salah satu dampak positif jika artikel, opini, berita yang ditulis bisa menginspirasi, menambah pengetahuan dan membawa banyak kemanfaatan untuk orang lain, akan tetapi, menjadi kontradiktif jika kemudian yang ditulis merupakan sesuatu yang sifatnya hoax dan tujuannya untuk menjatuhkan pihak-pihak tertentu, mengadu domba atau menyebarkan fitnah serta hal-hal yang tidak baik" (http://www. timesindonesia.co.id).

Pernyataan tersebut juga sesuai dengan hasil wawancara dan observasi yang peneliti lakukan dengan para informan. Melalui penelitian ini, peneliti mengeksplorasi adanya temuan baru berupa upaya membangun ketahanan nasional dalam komunikasi kesehatan bagi kalangan perempuan urban di Jakarta. Adapun tahapan hasil pemaparannya sebagai berikut.

Pertama, memastikan adanya sumber yang kredibel dan ahli di bidang kesehatan.

Ketika peneliti menelusuri secara lebih intensif kepada para informan, sebagian besar mengatakan bahwa langkah pertama yang diambil adalah menemukan sumber yang kredibel dan ahli di bidang kesehatan. Hal ini diupayakan untuk menghindari informasi kesehatan yang hoax.

Dwf, perempuan karir yang sudah tinggal lama di Jakarta, menyampaikan kepada peneliti dalam hasil wawancaranya:
"Iya saya sadar kok, sekarang ini era nya kan berbeda. Saya juga banyak mengalami perubahan, ya kalau ditanya soal proses komunikasi kesehatan ya, gimana caranya, sekarang sama dulu itu jauh beda banget, saya ngerasa terbantu berkat media digital sekarang, contohnya ya media sosial ini. Jadi, kalo dulu itu, saya suka dibawa langsung ke dokter sama ibu saya, kalo sekarang lain, saya udah punya anak sekarang, tapi dalam proses komunikasi kesehatan ini, saya milih searching dulu di mbah google, hehehe...Nah, tapi gak sembarangan juga, saya juga sadar kalo ada banyak efek negatif nya ya, apalagi sekarang tuh lagi musim nya hoax, dikitdikit ya bilangnya hoax, makanya untuk menyikapi itu ya saya pastikan dulu kalo informasi kesehatannya ini berasal dari sumber yang kredibel, dokter atau ahli kesehatan lainnya. Kan sekarang tuh ada banyak aplikasi dan situs portal web yang berbasis percakapan dengan dokter juga, atau artikel yang ditulisnya oleh dokter. Ini cara untuk mencari sumber yang kredibel buat saya. Malahan ya, untuk cari dokter yang bagus juga, saya suka browsing dulu biar tau testimoni dari orang lain kayak gimana."

Pernyataan Dwf tersebut menunjukkan adanya peran media yang digunakan dalam menunjang proses komunikasi kesehatannya. Dwf juga menyepakati bahwa sebagai salah seorang dari perempuan urban yang hidup di era digital ini, untuk mengantisipasi berbagai informasi atau berita hoax, maka Dwf melakukan pemilihan sumber yang kredibel di bidang kesehatan, misalnya dokter atau tenaga kesehatan lainnya.

Informan selanjutnya, And, perempuan karir yang asli dari Jakarta ini juga meyakinkan peneliti melalui wawancara yang dilakukan peneliti sebagai berikut.

"Gue tau sekarang era nya udah serba digital, malahan kerjaan juga di kantor lebih 
sering dilakukannya komunikasi via skype aja, haha...ini namanya mengoptimalkan media digital tadi. Tapi kalo ditanya soal proses komunikasi kesehatan yang gue lakuin, kalo gue ngerasain sakit, ada keluhan atau nyeri di bagian badan, gue milih untuk browsing di situs portal dulu, sekarang banyak kok situs yang kredibel, cara bedainnya ya kita bisa liat di bagian home ya ada menu about yang ngejelasin tentang situs tersebut. Gue suka baca itu dulu, terus gue liat oh ada dokter-dokter yang kredibel nya nih, plus ada foto, tempat kerja, dan biodata lain lah, wah perfect nih. Kalo udah gini, gue ngerasa aman, haha... artinya gue masuk ke sumber yang tepat dan kredibel di bidang kesehatan. Soalnya gue takut juga lah kalo proses komunikasi yang gue lakuin itu ternyata isinya hoax belaka, ngeri lah.

Berdasarkan penuturan dari And di atas, peneliti melihat ada upaya yang sama dilakukan dengan informan sebelumnya, yaitu untuk membangun ketahanan informasi nasional dalam komunikasi kesehatan. Sebagai tahap pertama yang dilakukan, And pun mengatakan bahwa dia akan memastikan sumber komunikator yang kredibel, tepat, dan ahli di bidang kesehatan. Hal ini ditunjukkan dengan mencari tahu situs portal website yang dikunjungi tersebut merupakan situs resmi yang terdiri dari para dokter sebagai narasumber utama yang menyampaikan informasi kesehatan tersebut. And juga menyampaikan kekhawatirannya tentang informasi hoax, oleh karena itu dia pun berhati-hati sekali dalam memilih sumber yang tepat di bidang kesehatan.

Informan ketiga, Lda, perempuan karir yang tinggal lama di Jakarta ini, yang berprofesi sebagai pengajar di salah satu perguruan tinggi swasta di Jakarta, juga memaparkan pendapatnya tentang proses komunikasi kesehatan yang dilakukannya, di bawah ini.

\begin{abstract}
"Kalau gue sih ngeliatnya karena sekarang itu musim berita hoax ya, berarti gue harus teliti banget milih sumber. Gue juga setuju kalo di kalangan generasi urban saat ini, proses komunikasi kesehatan itu kebanyakan dilakukan dengan mengoptimalkan media digital, termasuk media sosial. Jadi, emang bener juga kalo cara kayak gini nih rentan banget sama berita hoax. Ya susah juga emang menghindar dari berita hoax ini, makanya gue awali dari diri gue sendiri, soalnya efeknya itu bisa menimbulkan konflik, perdebatan, saling hujat, saling benci, ujung dari semua ini yang gue takutin itu perpecahan bangsa Indonesia, meretakkan persatuan dan kesatuan Indonesia. Dampak ini sebenernya yang seringkali ga kita sadarin".
\end{abstract}

Pernyataan yang disampaikan oleh Lda di atas, menghasilkan temuan baru tentang pentingnya ketahanan informasi nasional, yaitu adanya kekhawatiran informan di era digital ini tentang berita hoax yang akan berujung pada perpecahan bangsa atau retaknya persatuan dan kesatuan bangsa Indonesia. Oleh karena itu, Dnd menjawab untuk menyikapi hal tersebut, khususnya dalam proses komunikasi kesehatan, maka yang akan dilakukannya adalah memastikan sumber atau komunikator yang tepat, kredibel, dan ahli di bidang kesehatan.

Pernyataan Lda tersebut juga serupa dengan Kna, sebagai bagian dari kalangan perempuan urban yang tinggal di Jakarta. Kna yang semula adalah perempuan karir, setelah menikah dan mempunyai anak, saat ini memilih untuk menjadi ibu rumah tangga. Kna mengakui bahwa dia merupakan bagian dari kalangan perempuan urban yang juga menggunakan peran media digital, salah satunya media sosial.

"Hehe...emang era nya udah beda ya, sekarang ini ada media sosial yang ngebantu 
banget proses komunikasi, jadi mau gak mau, aku ikutan juga manfaatin media sosial ini. Misalnya, kalo lagi ngerasa sakit juga, bakal langsung kontak sama dokter, kan punya nomor WA-nya, kalo ada apa-apa, bisa komunikasi via WA, tapi emang gak cepet responnya, ya maklum lah ya, hehe.. Jadi, langkah lain ya browsing juga, terus kalo ada yang share soal info gini, awas obat-obatan berbahaya tidak berbadan POM, dll ya, pas liat eh ada obat yang suka aku minum, kan ngeri juga, bener gak yah ini, ya aku sih suka langsung mastiin dulu ke sumber yang kredibel, bisa dokter, perawat, atau tenaga medis lain. Tapi kalo dipikir, ngeri juga terus-terusan gitu, maksudnya informasi kesehatan itu menyebar terus, kalo gak bener, kan hoax itu, bisa bikin berabe, ya sama aja ujungnya dengan mengancam persatuan dan kesatuan bangsa".

Berdasarkan pemaparan para informan di atas, peneliti dapat mengeksplorasi bahwa adanya upaya membangun ketahanan informasi nasional dalam proses komunikasi kesehatan bagi kalangan perempuan urban di Jakarta, karena mayoritas proses komunikasi kesehatan tersebut berlangsung juga dalam media digital, maka yang dilakukan yaitu memastikan adanya sumber/ komunikator yang tepat, kredibel, dan ahli di bidang kesehatan. Hal ini ditandai dengan adanya identitas dokter yang memberikan informasi dalam situs tersebut.

Kedua, melakukan filterisasi kognitif tentang pesan kesehatan agar terhindar dari berita bohong/ berita hoax. Hal ini disepakati oleh para informan bahwa sebagai upaya membangun ketahanan informasi nasional dalam komunikasi kesehatan, maka para informan pun melakukan filterisasi kognitif tentang pesan kesehatan yang diterimanya. Ada salah satu contoh pengalaman yang dipaparkan oleh Dwf tentang filterisasi kognitif ini, sebagai berikut.
"Kalo aku sih, setelah meyakinkan diri bahwa sumbernya udah kredibel atau belum, langkah selanjutnya, aku memfilter pesan tersebut. Filterisasi kognitif itu penting banget buat aku ya, sama sih kalo ngobrol sama temen yang lain juga, kita harus punya filter kognitif, gak sembarangan percaya, aku pernah soalnya denger cerita nyata tentang ini, jadi ada orang yang ngelakuin pengobatan penyakitnya dengan browsing dan ngikutin petunjuk yang ada disitu, tanpa dia berobat ke dokter atau minimal cross check dulu bener gak info itu, sampai akhirnya penyakitnya gak kunjung sembuh, tapi malah bertambah parah. Ujungnya kan jadi nyalahin sumber informasi yang ada di web itu, ya jadi mengancam ketahanan informasi nasional."

Peneliti mencermati adanya upaya melakukan filterisasi kognitif tentang pesan yang diterima dalam proses komunikasi kesehatan tersebut. Meskipun pesan tersebut berisi tentang informasi kesehatan metode pengobatan penyakit, lalu diikuti begitu saja, tanpa melakukan pengecekan terlebih dahulu, maka akibat yang ditimbulkan bisa jadi penyakit yang dialaminya menjadi bertambah parah. Jadi, inilah pentingnya perlu melakukan filterisasi, yaitu penyaringan kognitif dari pesan yang diterima.

Ketiga, memilih media sebagai saluran komunikasi kesehatan yang relevan di bidang kesehatan. Hal ini ditunjukkan dari penuturan para informan yang juga tidak sembarangan dalam menggunakan media sebagai saluran komunikasi. Misalnya, pada pembahasan sebelumnya, peneliti melampirkan hasil wawancara dengan informan, And, yang mengatakan bahwa dia tidak asal-asalan dalam memilih media digital untuk mencari informasi kesehatan yang dibutuhkan. And juga memilih media situs portal yang kredibel, bisa ditunjukkan dengan adanya kejelasan 
Gambar 2

Media Digital Yang Digunakan Dalam Melakukan Proses Komunikasi Kesehatan

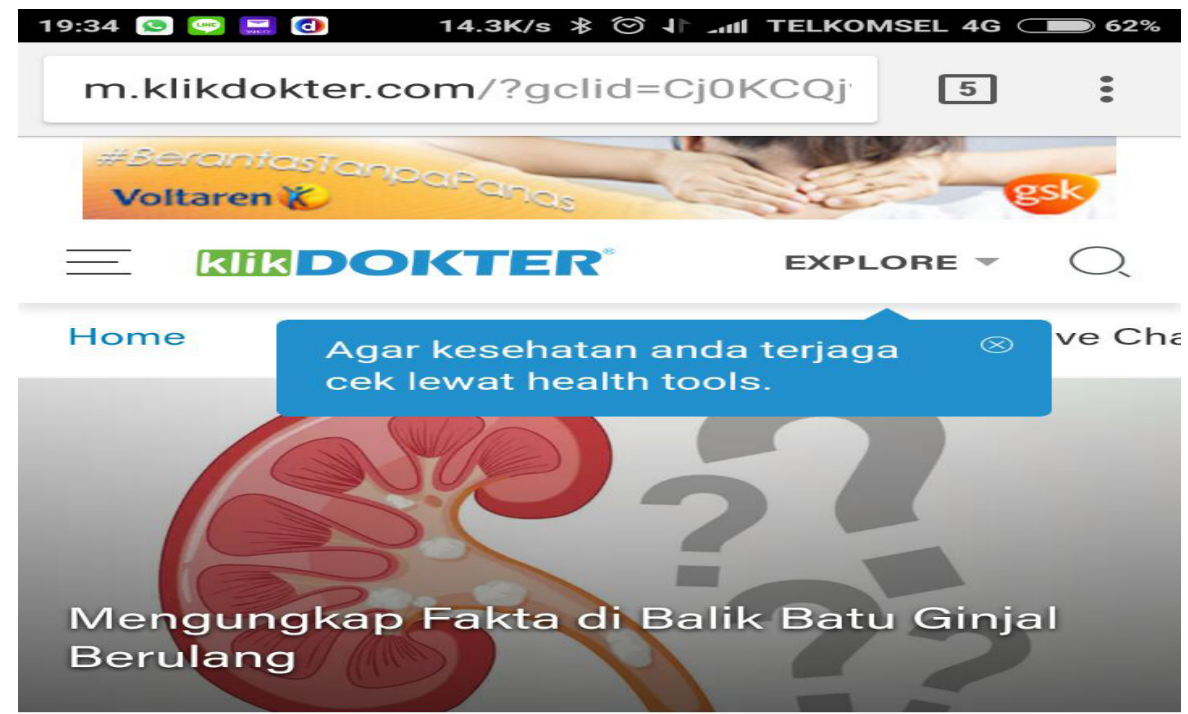

Jangan Tunggu Paru-Paru

Seperti Ini Untuk Berhenti Merokok

SPONSORED

Mioma di Rahim, Haruskah Dioperasi?

Sumber : m.klikdokter.com identitas media tersebut sebagai sumber terpercaya di bidang kesehatan.

Gambar 2 tersebut merupakan salah satu potongan gambar yang dikirimkan informan, And, kepada peneliti untuk memberi tahu proses komunikasi kesehatan yang dilakukannya melalui peran media digital, yaitu mencari situs portal resmi dan kredibel tentang kesehatan. Menurut pengakuan And, dia memilih proses komunikasi kesehatan dengan mengoptimalkan peran media agar And mengetahui pencegahan dari gejala sakit yang dirasakannya, tanpa harus berkonsultasi dengan dokter. Ketika ditanyakan lagi mengenai alasannya, berikut penuturannya.

"Iya, gue emang sengaja mengoptimalkan kecanggihan media digital saat ini, untuk

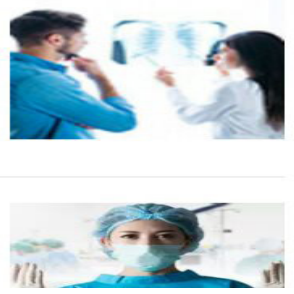

pencegahan sih, jadi gue tau kalo gue sakit ini kenapa gejalanya, harus kayak gimana dan ke dokter spesialis apa ya, soalnya biaya dokter spesialis di Jakarta itu mahal banget, bo...waktu gue alergi aja di dokter kulit, sekali pengobatan itu sampe ngabisin 2 juta, haha...bayangin aja...kalo dikitdikit gue sakit, gue langsung ke dokter spesialis. Nah, kalo udah tau kan gejala sama pencegahannya gimana, jadi waspada. Kalau emang perlu penanganan serius, baru gue ke dokter, hehe..."

Berdasarkan penuturannya tersebut, And juga memberikan potongan gambar kepada peneliti tentang cara yang dilakukannya dalam memilih media yang tepat dan kredibel di bidang kesehatan. Seperti yang telah diungkapkan dalam pembahasan sebelumnya, 
Gambar 3

Hasil Mesin Pencarian Google Yang Digunakan Dalam Memilih Situs Portal Resmi Dan Kredibel Bidang Kesehatan

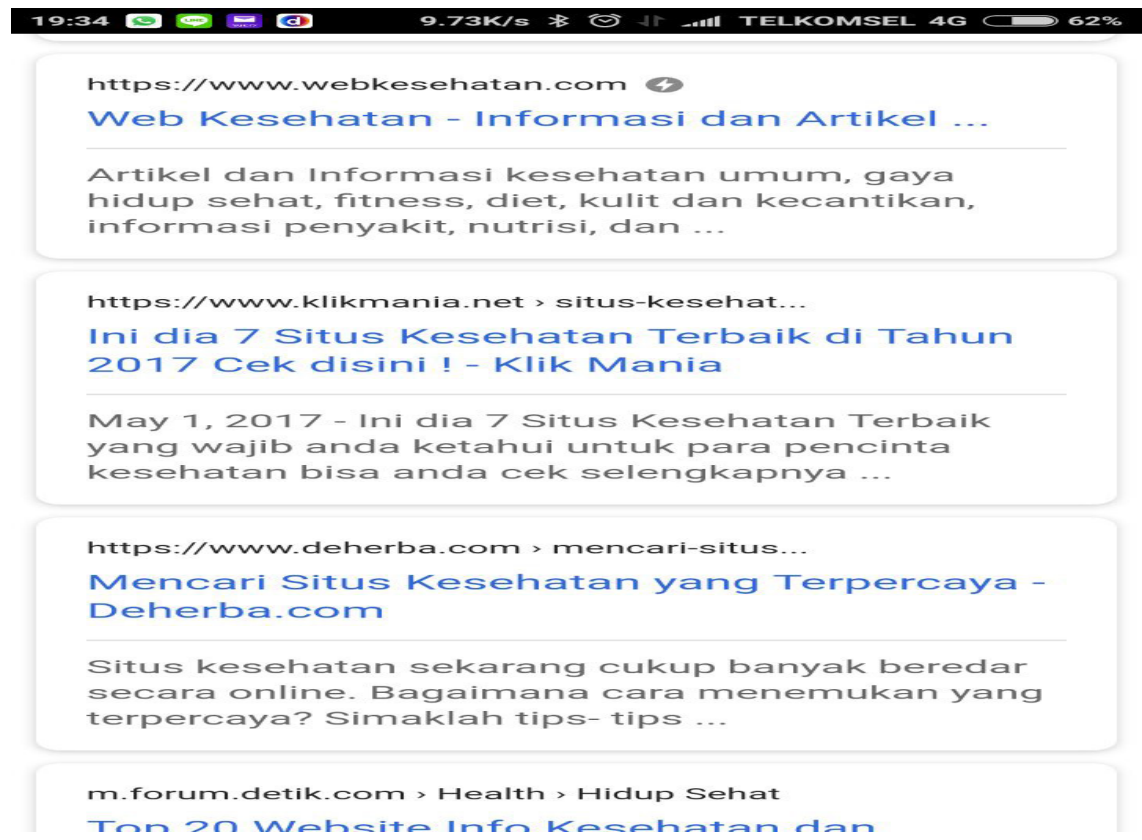

Sumber : https://www.webkesehatan.com

And biasanya menyelidiki dari hasil mesin pencarian google, lalu mengecek menu Home, Contact, atau About the Site, yang menunjukkan bentuk pertanggungjawaban resmi dari situs tersebut sebagai media/ saluran komunikasi kesehatan. Menurutnya, sebagai pembaca, kita harus bersikap aktif memilih, mengecek, membandingkan, dan menyaring media yang kredibel di bidang kesehatan.

Gambar 3 di atas sebagai salah satu hasil pencarian mesin google yang digunakan And dalam proses komunikasi kesehatan. Dalam gambar ini terlihat bahwa And juga memilih situs portal yang tidak sembarangan, tetapi mempertimbangkan berbagai unsur, khususnya segi kredibilitas situs portal tersebut. Jadi, And menyampaikan bahwa dia melakukan perbandingan pesan kesehatan yang disampaikan dalam situs tersebut dengan situs yang lainnya.
Keempat, bersikap aktif dalam melakukan cross check data tentang efek atau hasil dari pesan kesehatan . Para informan menegaskan bahwa sikap aktif ini perlu dimiliki bagi setiap individu dalam memperoleh pesan kesehatan yang meyakinkan. Misalnya, ketika Kna ingin mencari tahu tentang penyebab dari gatalgatal yang dialaminya, setelah memperoleh pesan kesehatan dari situs portal kesehatan, maka Kna mengecek pesan tersebut dengan bertanya kepada temannya yang bekerja sebagai tenaga kesehatan juga. Hal ini berguna untuk meyakinkan diri bahwa pesan yang telah diperoleh adalah benar, bukan informasi yang bersifat bohong/ hoax belaka.

Informan lainnya, Dwf menyampaikan kepada peneliti sebagai berikut.

"Saya juga suka langsung cross check informasi pesan itu, bener gak nih, cross check nya ke sumber yang kredibel dong, 
saya kan punya kontak WA dokter anak saya, jadi kalo ada pesan kesehatan yang meragukan, contohnya sih soal imunisasi, vaksin, tumbuh kembang anak ya, saya langsung WA dokter, walaupun jawabnya agak lama juga, tapi yang pasti kan dapet jawaban yang kredibel dari sumber yang ahli di bidang kesehatan juga. Jadi, kembali lagi sama kita yang harus aktif untuk mengecek dulu pesan itu bener gak, apalagi kalo ada evidence based-nya. Itu kalo kata dokter saya. Katanya, untuk membedakan pesan tentang tanaman ini mampu mengobati penyakit, nah kalau ada hasil uji klinis, evidence based yang tadi, baru bisa dikatakan benar, teruji secara klinis, gak sembarangan gitu”.

Kelima, bergabung dalam gerakan komunitas yang peduli tentang informasi kesehatan. Berdasarkan hasil wawancara dan observasi yang dilakukan peneliti, tidak semua informan memberikan pernyataan yang sama tentang langkah kelima ini. Tetapi ada satu informan, Dwf, perempuan karir yang juga telah berkeluarga dan memiliki anak, menyampaikan bahwa upaya yang telah dilakukannya dalam membangun ketahanan informasi nasional adalah dengan bergabung dalam gerakan komunitas yang peduli tentang informasi kesehatan. Menurut Dwf, sebagai seorang ibu, dia juga harus memiliki literasi kesehatan yang baik tentang perkembangan kesehatan anaknya. Kekhawatirannya tentang berita hoax inilah yang membuat dia mencari gerakan komunitas yang peduli dengan informasi kesehatan yang akurat dan berasal dari sumber yang kredibel.

Berbicara masalah komunitas, peneliti menjadi teringat salah satu artikel Aji (2017) yang dilansir dari http://www.tribunnews. com, diterbitkan pada 24 Mei 2107, berjudul "Lebih Bahaya, Berita Hoax harus Dicegah", yang menjelaskan pernyataan Koordinator
Komunitas Sapu Langit, Budi Purnomo Karjodihardjo, juga sebagai CEO Indonesia Media Center (IMC), bahwa berita hoax dapat berakibat fatal terhadap nyawa seseorang. Menurutnya, pemerintah dan para pegiat media sosial harus memberikan perhatian lebih. Dalam media online tersebut, dikatakan juga bahwa pembentukan Jaringan Anti Hoax Kesehatan (Jahkes) yang bersifat relawan sebagai bentuk kepedulian Komunitas Sapu Langit terhadap sesama dan alasan kemanusiaan.

Data di atas memperlihatkan bahwa gerakan komunitas memiliki kekuatan yang besar dalam membangun ketahanan informasi nasional di Indonesia, khususnya untuk menyikapi berbagai informasi dan berita bohong atau hoax semata. Hal inilah yang disampaikan oleh salah seorang informan peneliti, Dwf, saat ini juga telah bergabung dalam gerakan komunitas bernama "Smart Mommies". Komunitas ini berbagi informasi kesehatan yang berasal dari sumber kredibel, tepat, dan ahli di bidang kesehatan, misalnya para dokter sebagai narasumbernya.

\section{Teori Determinisme Teknologi}

Teori komunikasi yang relevan dalam penelitian ini yang berjudul "Membangun Ketahanan Informasi Nasional Dalam Komunikasi Kesehatan Bagi Kalangan Perempuan Urban Di Jakarta" adalah teori determinisme teknologi. Dalam perkembangan determinisme teknologi di abad 20, muncul seorang ahli filsafat dalam teori komunikasi yaitu Marshal McLuhan pertama kali pada tahun 1962 menuliskan ide dasar teori ini adalah bahwa perubahan yang terjadi pada berbagai macam cara berkomunikasi akan membentuk pula keberadaan manusia itu sendiri (Nurudin, 2007: 184). 
Teknologi membentuk individu bagaimana cara berpikir, berperilaku dalam masyarakat, dan teknologi tersebut akhirnya mengarahkan manusia untuk bergerak dari satu abad teknologi ke abad teknologi yang lain. McLuhan berpikir bahwa budaya manusia dibentuk oleh bagaimana cara manusia berkomunikasi. Ide dasar teori ini adalah bahwa perubahan yang terjadi pada berbagai macam cara berkomunikasi akan membentuk pula keberadaan manusia itu sendiri (Nurudin, 2007: 185).

Pertama, penemuan dalam teknologi komunikasi menyebabkan perubahan budaya. Hal ini relevan dengan hasil penelitian peneliti bahwa proses komunikasi kesehatan yang terjadi bagi kalangan perempuan urban di Jakarta saat ini telah berubah seiring perkembangan zaman. Perempuan urban juga melakukan proses komunikasi kesehatan dengan mengoptimalkan media digital.

Kedua, perubahan di dalam jenis-jenis komunikasi akhirnya membentuk kehidupan manusia. Dalam hal ini, peneliti juga melihat bahwa perubahan dalam perkembangan teknologi komunikasi ini membentuk proses komunikasi dalam kehidupan manusia. Para informan dalam penelitian ini juga melakukan perubahan proses komunikasi kesehatan dengan mengoptimalkan media digital sebagai saluran komunikasi tersebut. Hal ini juga yang mengancam ketahanan informasi nasional yang ditandai dengan menyebarnya pesan kesehatan yang bersifat hoax belaka.

Ketiga, sebagaimana yang dikatakan McLuhan bahwa "Kita membentuk peralatan untuk berkomunikasi, dan akhirnya peralatan untuk berkomunikasi yang kita gunakan itu akhirnya membentuk atau mempengaruhi kehidupan kita sendiri”. Hal ini jelas terasa dalam perubahan perkembangan media digital dalam proses komunikasi kesehatan. Manusia belajar, merasa, dan berpikir terhadap apa yang akan manusia lakukan karena pesan yang diterima teknologi komunikasi menyediakan untuk itu. Artinya, teknologi komunikasi menyediakan pesan dan membentuk perilaku manusia sendiri. Secara khusus, konvergensi teknologi informasi menyebabkan bergesernya pola perilaku manusia, dalam hal ini adalah kalangan perempuan urban tersebut, dalam berkomunikasi satu sama lain.

Dalam penelitian yang telah dilakukan peneliti (2016) tentang "Perubahan Media Komunikasi Dalam Pola Komunikasi Keluarga Di Era Digital" memperlihatkan hasil penelitian adanya teknologi komunikasi yang telah memasuki dalam perasaan manusia dan mempengaruhi kehidupan sehari-hari. Dalam hal ini, peneliti menganalisis fenomena perubahan teknologi informasi melalui penggunaan media dalam keluarga digital. Keluarga digital, yang mengoptimalkan peran teknologi informasi tentu ingin menggunakannya lagi dan terus menerus. Bahkan, McLuhan sampai pada kesimpulannya bahwa media adalah pesan itu sendiri, the medium is the message (Prasanti: 2016).

Begitupun halnya dengan penelitian peneliti kali ini. Peneliti ingin menggambarkan bahwa ketahanan informasi nasional yang dimiliki oleh seseorang akan berdampak pula pada proses komunikasi kesehatan yang dilakukannya. Dalam hal ini, peneliti mengangkat kalangan perempuan urban sebagai para informan penelitian. Berdasarkan hasil penelitian yang telah dilakukan, peneliti melihat adanya upaya membangun ketahanan informasi nasional dalam proses komunikasi kesehatan yang dilakukan kalangan perempuan urban di Jakarta. Peneliti juga mengeksplorasi 
Gambar 4

Model Membangun Ketahanan Informasi Nasional Dalam Komunikasi Kesehatan Bagi Perempuan Urban Di Jakarta

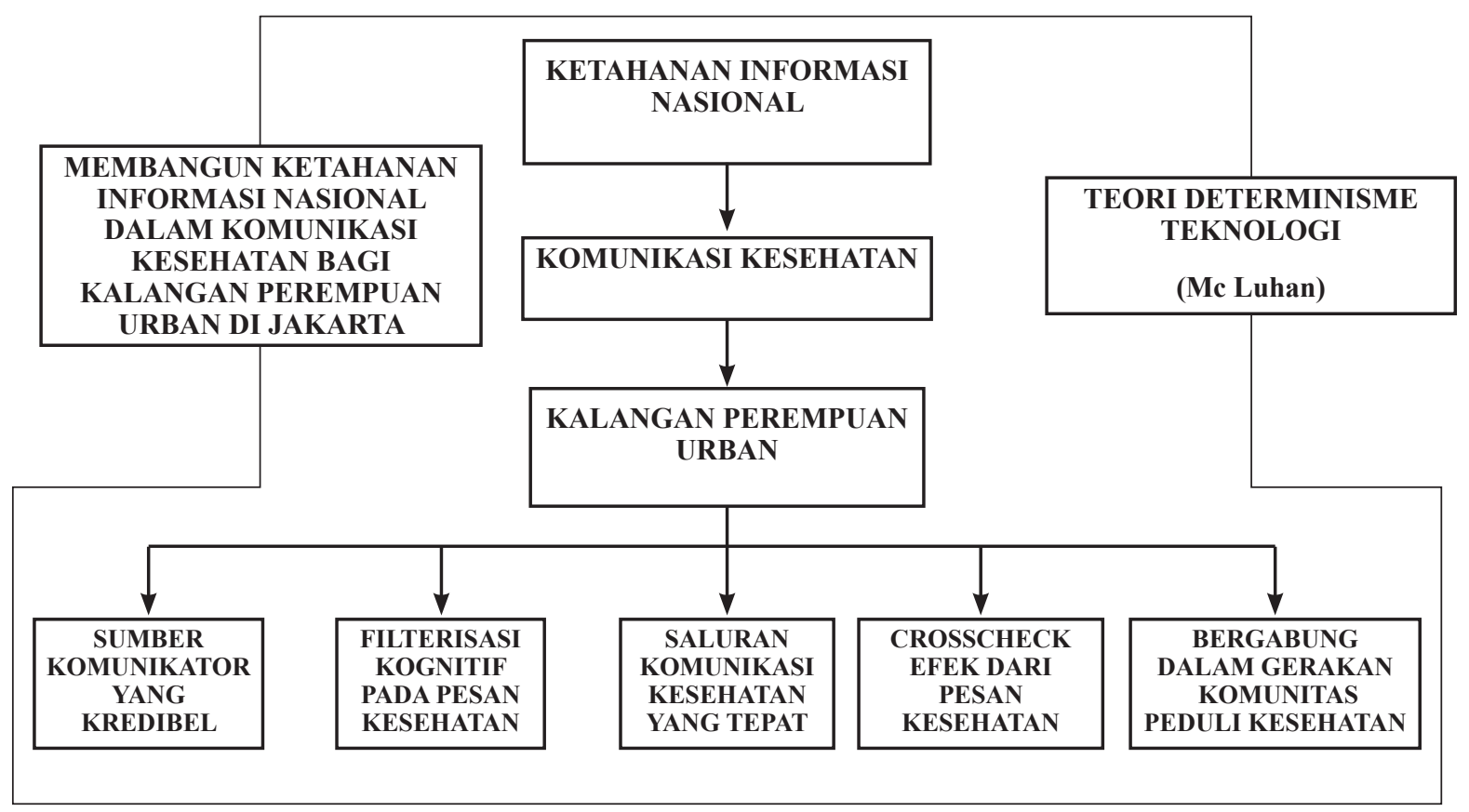

Sumber: Olahan Peneliti, 2017.

kehadiran media digital yang juga digunakan sebagai saluran komunikasi dalam proses komunikasi kesehatan bagi kalangan perempuan urban di Jakarta. Jika tidak ada tindakan yang dilakukan, hal ini mengakibatkan munculnya berbagai pesan kesehatan yang bersifat hoax, sehingga mengancam ketahanan informasi nasional. Oleh karena itu, melalui penelitian ini, peneliti mengidentifikasi adanya upaya yang dilakukan untuk membangun ketahanan informasi nasional dalam komunikasi kesehatan bagi kalangan perempuan urban di Jakarta, terdiri dari: sumber komunikator yang kredibel; filterisasi kognitif pada pesan kesehatan; saluran komunikasi kesehatan yang tepat; crosscheck efek/ hasil dari pesan kesehatan; dan bergabung dalam gerakan komunitas peduli kesehatan. Penelitian ini juga dianalisis dengan menggunakan teori determinisme teknologi dari McLuhan.
Dalam penelitian ini, peneliti juga mencoba mengeksplorasi hasil penelitian ini melalui alur model sederhana di bawah ini (lihat gambar 4).

\section{SIMPULAN}

Berdasarkan hasil penelitian berjudul "Membangun Ketahanan Informasi Nasional dalam Komunikasi Kesehatan bagi Kalangan Perempuan Urban di Jakarta", yang telah dieksplorasi dengan menggunakan metode studi kasus di atas, dapat ditarik simpulan sebagai berikut.

Pertama, pada era digital ini, perempuan urban pun melakukan proses komunikasi kesehatan dengan memanfaatkan media digital sebagai saluran komunikasinya. Peneliti mengeksplorasi adanya upaya membangun ketahanan informasi nasional dalam komunikasi kesehatan bagi kalangan perempuan urban di Jakarta. 
Kedua, upaya membangun ketahanan informasi nasional tersebut dilakukan dengan (1). Memastikan adanya sumber yang kredibel, tepat, dan ahli di bidang kesehatan; (2). Melakukan filterisasi kognitif pada pesan kesehatan yang diterima agar terhindar dari berita bohong/ berita hoax; (3). Memilih media sebagai saluran komunikasi kesehatan yang tepat di bidang kesehatan; (4) Bersikap aktif dalam melakukan crosscheck efek atau hasil dari pesan informasi kesehatan tersebut, ditunjukkan dengan adanya evidence based (hasil uji klinis) yang mendukung; (5). Bergabung dengan gerakan komunitas yang peduli kepada informasi kesehatan yang akurat.

\section{DAFTAR PUSTAKA}

Aji, Wahyu, (2017). "Lebih Bahaya, Berita Hoax Kesehatan Harus Dicegah",

h t t p : //www.tribunnews.com/ nasional/2017/05/24/

Amal, Ichlasul dan Armaidy Armawi, 2005, Keterbukaan Informasi dan Ketahanan Nasional. Yogyakarta: Gadjah Mada University Press.

Azzam, T. (2010). "Peran Strategis Pers Dalam Memperkuat Ketahanan Nasional”. Jurnal Ketahanan Nasional, 15(3), 33-48.

Creswell, J. W., 2010), Research Design: Pendekatan Kualitatif, Kuantitatif, dan Mixed. Yogjakarta: PT Pustaka Pelajar.

Fazriyati, W. (2011). "10 Keunikan Perempuan Indonesia". Harian Kompas/Kompas TV: FEMALE,http://female.kompas.com/ read/2011/10/30/12575615/10.Keunikan. Perempuan.Indonesia, diakses pada 13 Agustus 2017

Gaffar, A.(2012). "Sihir Iklan dalam Konsumsi Masyarakat Perkotaan". Jurnal Dinamika Perkotaan (JDP). Universitas Riau.
Lan, Thung Ju,2015. "Perempuan Dan Modernisasi" Jurnal Masyarakat \& Budaya, 17 (1), 17-28.

Liliweri,Allo, $12007 \backslash$,Dasar-dasar Komunikasi Kesehatan. Yogyakarta: Pustaka Belajar.

Mufidah, N. L. 2012, "Pola Konsumsi Masyarakat Perkotaan: Studi Deskriptif Pemanfaatan Foogcourt Oleh Keluarga" Jurnal Biokultur, 2, 157-178.

Mugasejati, N. P., \& Armawi, A. ,2000. "Ketahanan Nasional Dan Globalisasi: Sebuah Agenda Riset". Jurnal Ketahanan Nasional, 5(3), 43-60.

Mulyana, Deddy. 2002. Metode Penelitian Kualitatif : Paradigma Baru Ilmu Komunikasi dan Ilmu Sosial Lainnya. Bandung : Remaja Rosdakarya.

Muzaham, Fauzi, 1995, Memperkenalkan Sosiologi Kesehatan. Jakarta: Universitas Indonesia (UI).

Nazir, Moch., 2003, Metode Penelitian. Jakarta: Salemba Empat

Nediari, A.,2013, "Fenomena Mal Bagi Masyarakat Urban Di Jakarta”. Jurnal Humaniora. 4(1), 183-190

Nursaid, Arif, dan Armaidy Armawi. 2016. "Peran Kelompok Batik Tulis Giriloyo Dalam Mendukung Ketahanaan Ekonomi Keluarga" Jurnal Ketahanan Nasional, 25(5), 217-236.

Nurudin. (2007). Pengantar Komunikasi Massa. Jakarta: PT. Rajagrafindo Persada.

Pettegrew, A.M. (1982). "Context and Action in the Transformation of the Firm." Journal of Management Studies.

Prasanti, D.,2016. Perubahan Media Komunikasi Dalam Pola Komunikasi Keluarga Di Era Digital. Susunan Dewan Redaksi, 2527(1), 69 
Rinta, Leofio, 2015, "Pendidikan Seksual Dalam Membentuk Perilaku Seksual Positif Pada Remaja Dan Implikasinya Terhadap Ketahanan Psikologi Remaja". Jurnal Ketahanan Nasional, 163-174

Salim., Agus, 2006. Teori dan Paradigma Penelitian Sosial. Yogyakarta: Tiarawacana.

Saridewi, Valentina Siwi, Armaidy Armawi, Djoko Soerjo.,2016. "Penggunaan Teknologi Informasi Komunikasi Dalam Manajemen Asi Bagi Ibu Bekerja Guna Menjaga Ketahanan Keluarga". Jurnal Ketahanan Nasional, 27(1), 76-93.

Schiavo, R. (2007). Health Communication: Theory and Practice. San Fransisco: Jossey-Bass.

Suradinata, Ermaya. (2005). Hukum Dasar Geopolitik dan Geostrategi dalam Kerangka Keutuhan NKRI. Jakarta: Suara Bebas.

Tundung, Aris, Tri Kuntoro Priyambodo, Armaidy Armawi. 2017. "Tingkat Ketahanan Sistem Informasi Administrasi Kependudukan", Jurnal Ketahanan Nasional, 23(2), 21-33.
WHO, 2007, Everybody's Business: Strengthening Health System to Improve Health Outcome : WHO's Framework for Action WHO, ed., Geneva.

\section{Internet}

https://m.timesindonesia.co.id/ read/142217/20170210/163054/penelitilapangan-lsi-berita-hoax-mengancamkeutuhan-nkri/, diakses pada 11 Agustus 2017

http://www.kompasiana.com/oktina21/ ketahanan-informasi-dan-berita-hoax, diakses pada 11 Agustus 2017

https://www.kemhan.go.id/2015/06/23/ kemhan-dan-kemkes-tandatanganikesepakatan-kerjas ama-bidangkesehatan.html, diakses pada 12 Agustus 2017

https://www.webkesehatan.com

\section{Wawancara}

1. Adn, perempuan karir, Jakarta

2. Lda, perempuan karir, Jakarta

3. Dwf, perempuan karir, Jakarta

4. Kna, ibu rumah tangga, Jakarta 